\title{
Research on Influences of Individual Social Network on Startups of Returned Migrant Workers
}

\author{
Dan Yang \\ School of Management \\ China West Normal University \\ Nanchong, China 637002
}

\begin{abstract}
Researches show, social network has been a great help and promotion for the business establishment and operation. Based on returned rural migrant workers at $\mathrm{X}$ city, Sichuan Province, this article makes a questionnaire survey on 112 startup owners who are returned rural migrant workers, and Factor Analysis Method is used to research the roles of individual social network in the business startup and operation. The research results show, 6 factors among individual social networks including families relatives, clients, suppliers, banks, opponents and local authorities have played an important role in the business startup, of which, clients and suppliers have obvious effect in promoting the business operation. During the business establishment and operation, startup owners should make full use of three social resources including external workers, industrial institutions and local authorities.
\end{abstract}

Keywords—social network; returned rural migrant workers; business startup; Sichuan province

\section{INTRODUCTION}

Michael Song et al (2008) thought that social network is a collection of a string of nodes connecting social relations (such as friendship and transaction, etc) [1]. Seen for researches related to social networks, the objects in social networks can be persons, groups, organizations, areas and regional economy and so on. As a resource circulation channel and resource, social network is an efficient means for small enterprises to get resources and achieve the business development. With the developing economy around the world, social network has been playing a more and more important role in developing small enterprises, which are mainly reflected in three aspects: First of all, enterprises may get complementary resources to make up for the deficiency of the enterprises; second, information function mainly includes information availability, timeliness and reference; at last, helpful social network can promote exchanges and communications between employees, promoting the union and trust inside small enterprises in order to form a sound environmental atmosphere in enterprises.

Seen from RBV theory, the business startup cannot be separated from supporting resources, and the foundation for an enterprise to win in competition and develop is to get adequate resources to survive itself (Baron, 2004) [2].

Supported by the Fundamental Research Funds of China West Normal University (Grant No. 17E010)
Practices prove that medium and small enterprises may get a great number of helps from social network such as business resources; besides, it has a key role for cooperation and exchanges between enterprises. There are many research achievements concerning the enterprise operation and development through social network, yet few researches are conducted on the business startup by farmers, especially little is done under the Chinese national situations. Therefore, this article takes returned rural migrant workers as objects, analyzing the influences of social network on their business startup and trying to draw a conclusion with theoretical significance and practical value.

\section{LITERATURE BACKGROUND}

Startup is a course of information access and resources integration, in addition to individual factors, the startup also widely depends on individual resources. Luo (1997) [3]'s researches on small enterprises in Taiwan show, small enterprises owners tend to get capitals and market opportunities through individual network. Zhao, et al (2005) [4]'s researches prove that startupppers have make full use of social network to dig up chances that startup owners find in startup resources, the bigger the social network scale is, the more individual can get social resources, the more help and solutions they will get when facing uncertain environment. In the meantime, some scholars have conducted empirical researches on the influences of individual social network on startup intention. Jiang Jianyong (2012) [5]'s researches prove that individual social network has obviously positive influence on the startup intention. Wu Xiaobo et al (2014) [6 have proved that individual social network, through some of media of self efficiency in startup, can produce positive influence on the startup intention. Most of researchers (Zhu Feng, et al, 2013 [7] and Zhu Honggen, et al 2013[8]) have discovered that the social network of startup owners plays an important role in forming the startup intention.

During individual startup, the strong ties in social network of startup owners, especially the attitudes of family members, will influence how they treat and evaluate the startup; likewise, for many startup owners, whether startup owners will launch startup or not will need the emotional support of family members and friends. In addition, potential startup owners have limited resources, it is necessary for them to have the helps from family members, relatives and 
friends to overcome the restriction in resources, so the strong ties they hold can strengthen their confidences in startup, solidifying their intention in startup. Sequeira (2011) [9's researches proved that individual strong ties can reinforce their intention in startup and promote the initial startup conducts, however, individual weak ties may promote to carry out the initial startup.

During the business operation and development, both formal and informal networks are important parts of social networks for small business owners, of which, the formal network mainly includes cooperative enterprises or organizations, relevant laws and regulations, the informal network mainly includes the business owner's family members, relatives, friends, clients, suppliers and so on. Granovetter (1973) [10] divides the relations in social network into strong ties and weak ties. The strong ties are based on a network where family members or friends are core parts, higher confidences exist between them. Relying on the strong ties, the business owners speed up the information transfer, promote cooperation is problem solution so as to increase the enterprises' performances [11].

Seen from the literatures, we can find that the individual social network of startup owners may provide resources support for the business startup, operation and development, and to rely on individual social network to promote the business development has become an important mode for small business development. Formation of social network is a necessary condition for any business startup and successful operation. The individual external social network of startup owners can meet what the business development needs and promote the business development.

\section{RESEARCH DESIGN}

$\mathrm{X}$ city, Sichuan Province is selected as research object in this article, and from Sep 2017 to Oct 2017, a survey was conducted on 112 returned rural migrant workers who started businesses at hometown. The questionnaires targeted three dimensions including importance of individual social network, actual effect and communication frequency, fivepoint Likert scale method and spss21.0 software was adopted for data analysis. With regard to the gender composition, male recipients surveyed account for $52.7 \%$, female $47.3 \%$; most are young people, those aged 21-30 surveyed account for $47.3 \%$, those aged $31-40$ account for $30.4 \%$; those aged 41-50 account for 9.8\%; those aged 20 or les account for $7.1 \%$ only. Refer to "Table I", "Table II", and "Table III" for descriptive statistics of startup owners in social network.
TABLE I. DESCRIPTIVE STATISTICS OF IMPORTANCE OF INDIVIDUAL SOCIAL NETWORK TO STARTUP

\begin{tabular}{|l|l|l|l|l|}
\hline \multicolumn{1}{|c|}{ Type } & \multicolumn{1}{c|}{$\begin{array}{c}\text { Min } \\
\text { Value (M) }\end{array}$} & $\begin{array}{c}\text { Max } \\
\text { Value (X) }\end{array}$ & $\begin{array}{c}\text { Average } \\
(\mathbf{E})\end{array}$ & $\begin{array}{c}\text { Standard } \\
\text { Deviation }\end{array}$ \\
\hline Family members and relatives & 1.00 & 5.00 & 4.1429 & 1.02980 \\
\hline Classmates and friends & 1.00 & 5.00 & 3.8929 & 1.02542 \\
\hline Clients & 1.00 & 5.00 & 4.3393 & .98231 \\
\hline Suppliers & 1.00 & 5.00 & 4.3125 & .87024 \\
\hline Bank or financial institution & 1.00 & 5.00 & 4.1250 & .96912 \\
\hline Opponents & 1.00 & 5.00 & 4.0982 & .86950 \\
\hline Other industrial enterprises & 1.00 & 5.00 & 3.6786 & .97919 \\
\hline Agency Service & 1.00 & 5.00 & 3.5179 & 1.05679 \\
\hline Industrial association and society & 1.00 & 5.00 & 3.7143 & .99030 \\
\hline Authorities & 1.00 & 5.00 & 4.1429 & .92860 \\
\hline
\end{tabular}

Seen from "Table I", with regard to the importance to small businesses, startup owners think that the relations in ten points all are mighty important, of which, family members and relatives, clients and suppliers and authorities have the highest average value for startup, reaching 4.0+, which turns out that most business owners value the supports from family members and relatives, clients and suppliers and authorities.

TABLE II. DEscriptive Statistics of Actual EFFECT OF SOCIAL NETWORK SUPPORTING THE STARTUP

\begin{tabular}{|l|l|l|l|l|}
\hline \multicolumn{1}{|c|}{ Type } & \multicolumn{1}{|c|}{$\begin{array}{c}\text { Min } \\
\text { Value (M) }\end{array}$} & $\begin{array}{c}\text { Max } \\
\text { Value (X) }\end{array}$ & $\begin{array}{c}\text { Average } \\
(\mathbf{E})\end{array}$ & $\begin{array}{l}\text { Standard } \\
\text { Deviation }\end{array}$ \\
\hline Family members and relatives & 1.00 & 5.00 & 3.7589 & .94197 \\
\hline Classmates and friends & 1.00 & 5.00 & 3.8304 & .94810 \\
\hline Clients & 1.00 & 5.00 & 4.1786 & .89255 \\
\hline Suppliers & 1.00 & 5.00 & 4.0000 & .92998 \\
\hline Bank or financial institution & 1.00 & 5.00 & 3.9018 & .98603 \\
\hline Opponents & 1.00 & 5.00 & 3.6964 & .95709 \\
\hline Other industrial enterprises & 1.00 & 5.00 & 3.5446 & .96692 \\
\hline Agency Service & 1.00 & 5.00 & 3.6607 & 1.04454 \\
\hline Industrial association and society & 1.00 & 5.00 & 3.7232 & .97915 \\
\hline Authorities & 1.00 & 5.00 & 3.9018 & 1.02192 \\
\hline
\end{tabular}

"Table II" indicates, in the actual effect of individual social network of startup owners in startup, only the average value of clients and suppliers reaches 4.0+, which turns out that though the business owners value the supports of family members and relatives, clients, suppliers and authorities, actually only the supports of clients and suppliers are highest. The results prove the research conclusion of Burt (1992) [12]: Generally the weak ties vague to define can provide the most important commercial chances for a business and promote its development.

TABLE III. DESCRIPTIVE STATISTICS OF COMMUNICATION FREQUENCY

\begin{tabular}{|l|l|l|l|l|}
\hline \multicolumn{1}{|c|}{ Type } & $\begin{array}{c}\text { Min } \\
\text { Value }(\mathbf{M})\end{array}$ & $\begin{array}{c}\text { Max } \\
\text { Value (X) }\end{array}$ & $\begin{array}{c}\text { Average } \\
(\mathbf{E})\end{array}$ & $\begin{array}{l}\text { Standard } \\
\text { Deviation }\end{array}$ \\
\hline Family members and relatives & 1.00 & 5.00 & 3.9643 & .86918 \\
\hline Classmates and friends & 1.00 & 5.00 & 3.7768 & .90752 \\
\hline Clients & 1.00 & 5.00 & 4.0804 & .86095 \\
\hline Suppliers & 1.00 & 5.00 & 4.0000 & .99549 \\
\hline Bank or financial institution & 1.00 & 5.00 & 3.6786 & .90259 \\
\hline Opponents & 1.00 & 5.00 & 3.6250 & .83962 \\
\hline Other industrial enterprises & 1.00 & 5.00 & 3.4554 & .93855 \\
\hline Agency Service & 1.00 & 5.00 & 3.4821 & .98623 \\
\hline Industrial association and society & 1.00 & 5.00 & 3.6696 & .98993 \\
\hline Authorities & 1.00 & 5.00 & 3.6339 & 1.01338 \\
\hline
\end{tabular}


"Table III" indicates that most business owners often keep communications with ten social networks of their own, of which, the communication frequencies with clients and suppliers are the highest, whose average value reaches $4.0+$. It turns out that in the opinion of the business owners, the communications with the two may bring the max help to the business development.

\section{RESEARCH AND ANALYSIS}

Before the factor analysis, first, just analyze the questionnaire reliability. Statistics show, the questionnaire's Cronbach's alpha is 0.963, it means the questionnaire reliability of this article is high, and the questionnaire data is creditable. KMO value is 0.765 , which turn out the questionnaire has higher validity, applicable for the factor analysis.

This article adopts the factor analysis method to analyze the support importance, actual effect and communication frequency, the common factors are extracted according to characteristic value exceeding 1 , and the varimax orthogonal rotation is used for twiddling factors, and the items with the same components are grouped.

\section{A. Factor Analysis of the Supports of Individual Social Network to Startup Importance}

Factor analysis is conducted on the support importance in the questionnaire to get the total variance explained, refer to "Table IV".

TABLE IV. TOTAL VARIANCE EXPlaINED CONCERNING THE SUPPORTS OF INDIVIDUAL SOCIAL NETWORK TO STARTUP IMPORTANCE

\begin{tabular}{|c|c|c|c|c|c|c|c|c|c|}
\hline \multicolumn{10}{|c|}{ Total Variance Explained } \\
\hline \multirow[b]{2}{*}{ No } & \multicolumn{3}{|c|}{ Initial Characteristic Value } & \multicolumn{3}{|c|}{ Extracted Load Quadratic Sum } & \multicolumn{3}{|c|}{ Rotation Load Quadratic Sum } \\
\hline & Total & $\begin{array}{c}\text { Variance } \\
\text { percentage }\end{array}$ & Accumulated \% & Total & $\begin{array}{c}\text { Variance } \\
\text { percentage }\end{array}$ & Accumulated \% & Total & $\begin{array}{c}\text { Variance } \\
\text { percentage }\end{array}$ & Accumulated \% \\
\hline 1 & 3.583 & 35.833 & 35.833 & 3.583 & 35.833 & 35.833 & 2.633 & 26.331 & 26.331 \\
\hline 2 & 1.821 & 18.213 & 54.046 & 1.821 & 18.213 & 54.046 & 1.981 & 19.811 & 46.142 \\
\hline 3 & .940 & 9.405 & 63.451 & .940 & 9.405 & 63.451 & 1.731 & 17.309 & 63.451 \\
\hline 4 & .813 & 8.127 & 71.578 & & & & & & \\
\hline 5 & .675 & 6.748 & 78.325 & & & & & & \\
\hline 6 & .546 & 5.458 & 83.784 & & & & & & \\
\hline 7 & .509 & 5.088 & 88.872 & & & & & & \\
\hline 8 & .445 & 4.445 & 93.317 & & & & & & \\
\hline 9 & .393 & 3.927 & 97.244 & & & & & & \\
\hline 10 & .276 & 2.756 & 100.000 & & & & & & \\
\hline
\end{tabular}

Seen from "Table IV", characteristics values of the first three factors are bigger, which can explain the $63.451 \%$ variations of ten variables, rename the three factors: first, external personnel; second, industrial agencies, third, authorities. The max variance method is used for orthogonal rotation to get a factor load matrix as shown in "Table V".

TABLE V. FACTOR LOAD MATRIX CONCERNING THE SUPPORTS OF INDIVIDUAL SOCIAL NETWORK TO STARTUP IMPORTANCE

\begin{tabular}{|c|c|c|c|c|}
\hline \multirow{2}{*}{ Factor Type } & \multirow{2}{*}{ Variable } & \multicolumn{3}{|c|}{ Components } \\
\hline & & 1 & 2 & 3 \\
\hline \multirow{4}{*}{ External personnel } & Importance of supports from family members and relatives & .823 & .177 & -.008 \\
\hline & Importance of supports from classmates and friends & .733 & -.043 & 163 \\
\hline & Importance of supports from clients & 819 & 272 & -.101 \\
\hline & Importance of supports from suppliers & .491 & .534 & -.035 \\
\hline \multirow{3}{*}{ Industrial agencies } & Importance of supports from opponents & 685 & -.047 & .396 \\
\hline & Importance of supports from other industrial businesses & .031 & .589 & 297 \\
\hline & Importance of supports from agency service & .140 & 326 & .770 \\
\hline \multirow{3}{*}{ Authorities } & Importance of supports from banks or financial institutions & .034 & 219 & .834 \\
\hline & $\begin{array}{l}\text { Importance of supports from industrial associations and } \\
\text { societies }\end{array}$ & .076 & 698 & .383 \\
\hline & Importance of supports from authorities & .092 & .773 & .113 \\
\hline
\end{tabular}

\section{B. Factor Analysis of the Supports of Individual Social}

\section{Network to Startup Effect}

Likewise, factor analysis is conducted on startup effect under the individual network support in the questionnaire to get the total variance explained, refer to Table VI. 


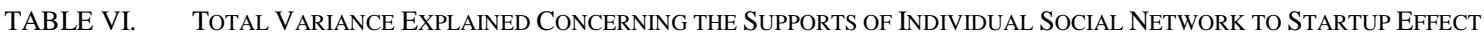

\begin{tabular}{|c|c|c|c|c|c|c|c|c|c|}
\hline \multirow[b]{2}{*}{ No. } & \multicolumn{3}{|c|}{ Initial Characteristic Value } & \multicolumn{3}{|c|}{ Extracted Load Quadratic Sum } & \multicolumn{3}{|c|}{ Rotation Load Quadratic Sum } \\
\hline & Total & $\begin{array}{c}\text { Variance } \\
\text { percentage }\end{array}$ & $\begin{array}{c}\text { Accumulated } \\
\%\end{array}$ & Total & $\begin{array}{c}\text { Variance } \\
\text { percentage }\end{array}$ & $\begin{array}{c}\text { Accumulate } \\
\mathrm{d} \%\end{array}$ & Total & $\begin{array}{c}\text { Variance } \\
\text { percentage }\end{array}$ & $\begin{array}{l}\text { Accumulated } \\
\%\end{array}$ \\
\hline 1 & 5.535 & 55.346 & 55.346 & 5.535 & 55.346 & 55.346 & 2.490 & 24.904 & 24.904 \\
\hline 2 & .920 & 9.200 & 64.546 & .920 & 9.200 & 64.546 & 2.433 & 24.327 & 49.231 \\
\hline 3 & .753 & 7.526 & 72.072 & .753 & 7.526 & 72.072 & 2.284 & 22.841 & 72.072 \\
\hline 4 & .684 & 6.838 & 78.911 & & & & & & \\
\hline 5 & .572 & 5.720 & 84.630 & & & & & & \\
\hline 6 & .505 & 5.048 & 89.678 & & & & & & \\
\hline 7 & .380 & 3.797 & 93.475 & & & & & & \\
\hline 8 & 292 & 2.924 & 96.399 & & & & & & \\
\hline 9 & .204 & 2.044 & 98.443 & & & & & & \\
\hline 10 & 156 & 1.557 & 100.000 & & & & & & \\
\hline
\end{tabular}

Seen from "Table VI", characteristics values of the first three factors are bigger, which can explain the $72.072 \%$ variations of ten variables, rename the three factors one by

one external personnel; industrial agencies and authorities. Then the max variance method is used for orthogonal rotation to get a factor load matrix as shown in "Table VII".

TABLE VII. FACTOR LOAD MATRIX CONCERNING THE SUPPORTS OF INDIVIDUAL SOCIAL NETWORK TO STARTUP EFFECT

\begin{tabular}{|c|c|c|c|c|}
\hline \multirow{2}{*}{ Factor Type } & \multirow{2}{*}{ Variable } & \multicolumn{3}{|c|}{ Component } \\
\hline & & 1 & 2 & 3 \\
\hline \multirow{4}{*}{ External personnel } & Effect of supports from family members and relatives & .084 & .715 & .467 \\
\hline & Effect of supports from classmates and friends & 279 & .800 & .163 \\
\hline & Effect of supports from clients & 248 & .553 & .354 \\
\hline & Effect of supports from suppliers & .400 & .703 & .016 \\
\hline \multirow{3}{*}{ Industrial agencies } & Effect of supports from opponents & .688 & .320 & .339 \\
\hline & Effect of supports from other industrial businesses & .827 & .348 & 217 \\
\hline & Effect of supports from agency service & .758 & 218 & .306 \\
\hline \multirow{3}{*}{ Authorities } & Effect of supports from banks or financial institutions & .184 & .211 & .844 \\
\hline & Effect of supports from industrial association and society & .440 & .392 & .660 \\
\hline & Effect of supports from authorities & .474 & .116 & .714 \\
\hline
\end{tabular}

\section{Factor Analysis of Communication Frequencies through}

\section{Individual Social Network}

At last, factor analysis is conducted on the communication frequencies through the individual network to get the total variance explained, refer to "Table VIII".

TABLE VIII. TOTAL VARIANCE EXPLAINED CONCERNING THE COMMUNICATION FREQUENCIES THROUGH INDIVIDUAL SOCIAL NETWORK

\begin{tabular}{|c|c|c|c|c|c|c|c|c|c|}
\hline \multicolumn{10}{|c|}{ Total Variance Explained } \\
\hline \multirow[b]{2}{*}{ No. } & \multicolumn{3}{|c|}{ Initial characteristic value } & \multicolumn{3}{|c|}{ Extracted load quadratic sum } & \multicolumn{3}{|c|}{ Rotation load quadratic sum } \\
\hline & Total & Variance percentage & Accumulated \% & Total & $\begin{array}{c}\text { Variance } \\
\text { percentage }\end{array}$ & Accumulated \% & Total & $\begin{array}{c}\text { Variance } \\
\text { percentage }\end{array}$ & Accumulated \% \\
\hline 1 & 4.196 & 41.964 & 41.964 & 4.196 & 41.964 & 41.964 & 2.468 & 24.677 & 24.677 \\
\hline 2 & 1.504 & 15.035 & 56.999 & 1.504 & 15.035 & 56.999 & 1.803 & 18.032 & 42.709 \\
\hline 3 & .967 & 9.671 & 66.670 & .967 & 9.671 & 66.670 & 1.666 & 16.661 & 59.370 \\
\hline 4 & 908 & 9.080 & 75.750 & .908 & 9.080 & 75.750 & 1.638 & 16.379 & 75.750 \\
\hline 5 & 674 & 6.735 & 82.485 & & & & & & \\
\hline 6 & .568 & 5.683 & 88.168 & & & & & & \\
\hline 7 & .449 & 4.494 & 92.662 & & & & & & \\
\hline 8 & .337 & 3.371 & 96.034 & & & & & & \\
\hline 9 & .234 & 2.336 & 98.370 & & & & & & \\
\hline 10 & .163 & 1.630 & 100.000 & & & & & & \\
\hline
\end{tabular}

Seen from "Table VIII", characteristics values of the first four factors are bigger, which can explain the $75.750 \%$ variations of ten variables, rename the four factors one by one family members and friends, external personnel; authorities and industrial agencies. Then the max variance method is used for orthogonal rotation to get a factor load matrix as shown in "Table IX". 


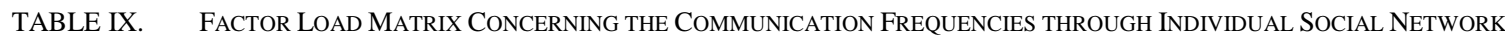

\begin{tabular}{|c|c|c|c|c|c|}
\hline \multirow{2}{*}{ Factor Type } & \multirow{2}{*}{ Variable } & \multicolumn{4}{|c|}{ Component } \\
\hline & & 1 & 2 & 3 & 4 \\
\hline \multirow{2}{*}{$\begin{array}{l}\text { Family member } \\
\text { and friends }\end{array}$} & Communication frequencies with family members & 148 & .061 & .821 & 189 \\
\hline & Communication frequencies with classmates and friends & 205 & .181 & .826 & .184 \\
\hline \multirow{2}{*}{ External personne } & Communication frequencies with clients & .057 & .283 & .242 & .835 \\
\hline & Communication frequencies with suppliers & 241 & -.057 & .148 & .841 \\
\hline \multirow[t]{2}{*}{ Authorities } & $\begin{array}{l}\text { Communication frequencies with banks or financial } \\
\text { institutions }\end{array}$ & .162 & .775 & .096 & .214 \\
\hline & Communication frequencies with authorities & 276 & .818 & .103 & .010 \\
\hline \multirow{4}{*}{ Industrial agencies } & Communication frequencies with opponents & .760 & .281 & .005 & .302 \\
\hline & Communication frequencies with other industrial businesses & 843 & .068 & .200 & .125 \\
\hline & Communication frequencies with agency service & .805 & .293 & .218 & -.055 \\
\hline & $\begin{array}{l}\text { Communication frequencies with industrial association and } \\
\text { society }\end{array}$ & .551 & .495 & .349 & -.089 \\
\hline
\end{tabular}

\section{CONCLUSION}

- During the business startup and operation by returned rural migrant workers, six factors in the social society including family members and relatives, clients, suppliers, banks or financial institutions, opponents and authorities play an important in the startup; clients and suppliers have the most obvious effect in promoting the business operation, therefore, the business owners are willing to keep frequent communications with clients and suppliers.

- Within the social network of startup owners, main factors for the startup of returned rural migrant workers include: external personnel (clients and suppliers), industrial agencies (opponents, other industrial businesses and agency service) and authorities (banks, industrial association and governmental sectors). In order to succeed in startup, the returned rural migrant workers have to make full use of the social network resources of the three points.

\section{REFERENCES}

[1] Michael Song, KseniaPodoynitsyna, Hans van der Bij, Johannes I., M., Halman, 2008, "Success Factors in New Ventures: A Metaanalysis", Journal of Product Innovation Management, 25 (3), pp. 727.

[2] Baron R A. The cognitive perspective: a valuable tool for answering entrepreneurship's basic "why" question[J]. Journal of Business Venturing, 2004,19(2):221-239.

[3] Luo J. D. The significance of network in the initiation of small business in Taiwan [J]. Social Forum 1997,12 (2): 297-317.

[4] Zhao H, Seibert S E, Hills G E. The mediating role of self-efficacy in the development of entrepreneurial intentions. [J]. Journal of Applied Psychology, 2005, 90(6):1265-72.

[5] Jiang Jianyong, Guo Hongdong, Atmosphere for Startup, Social Network and Intention of Farmers for Startup [J]. China Rural Survey, 2012(2): 20-27.

[6] Wu Xiaobo, Zhang Chaoqun, Wang Ying, Research on Relations between Social Network, Startup Effect and Intentions[J]. Science Research Management
[7] Zhu Feng, Huang Xiaochen, Analysis of Factors Influencing Chancebased Willing of Startup Owners [J]. On Economic Problems, 2013(6):40-43

[8] Zhu Honggen, Kang Lanyuan, Financial Environment, Policy Support and Farmers' Wills to Startup

[9] Jennifer sequeira, stephen 1. Mueller, jeffrey e. Mcgee. The influence of social ties and self-efficacy in forming entrepreneurial intentions and motivating nascent behavior[J]. Journal of Developmental Entrepreneurship, 2011, 12(3):275-293

[10] GranovetterM. The Strength of weak ties [J]. American Journal of Sociolog,1973,78: 1360-1380.

[11] UzziB. Social Structure and Competition in Interfirm Networks: The Paradox of Embeddedness [R]. Administrative Science Quarterly, 1997,42:35- 67.

[12] Burt R. Structural Holes, The Social Structure of Competition [M]. Harvard University Press, Boston, MA.1992. 